\title{
The Relationship between the Burnout Levels of Music Teachers and Their Personalities
}

\author{
Deniz Beste ÇEVIK KILIÇ \\ ${ }^{1}$ Necatibey Education Faculty, Balıkesir University, Balıkesir, Turkey \\ Correspondence: Deniz Beste ÇEVIK KILIÇ, Necatibey Education Faculty, Balıkesir University, Balıkesir, \\ Turkey. Tel: 90-266-241-1212. E-mail: beste@balikesir.edu.tr
}

Received: September 8, 2017

doi:10.5539/ies.v11n2p38

\author{
Accepted: October 24, $2017 \quad$ Online Published: January 26, 2018 \\ URL: https://doi.org/10.5539/ies.v11n2p38
}

\begin{abstract}
The aim of this study was to examine the relationship between the burnout levels of music teachers and their personalities. The research consisted of 278 music teachers who were selected from various places throughout Turkey via subjective, convenience sampling method. For data collection, the 'Personal Information Form', 'Adjective Based Personality Test' and 'Maslach Burnout Scale' were used. The research involved both quantitative and qualitative dimensions. The data were analyzed by quantitative t-test, multiple regression analysis and Pearson's correlation coefficient. Data for the qualitative dimension of the research were obtained from semi-structured interviews conducted with 5 music teachers. Negative, significant relationships were determined between extroversion, conscientiousness, agreeableness, openness and general burnout, while a positive, significant relationship was determined between neuroticism and general burnout. The burnout variable was found to have a statistically significant effect on the openness, neuroticism and conscientiousness dimensions of the personality types. The effects of conscientiousness and openness dimensions were not, however, found to be significant. The music teachers who had characteristics of extroversion and conscientiousness were found to have higher levels of burnout if they have the characteristics of neuroticism that reduce their exhaustion. The findings of the research show that the effect of personality types on burnout is important.
\end{abstract}

Keywords: teacher, music teacher, burnout, personality

\section{Introduction}

Although the concept of personality, as an integral aspect of social life, has attracted attention for centuries an integral part of human's social life, it wasn't until the 1930s, when personality psychology emerged as its own discipline, separate from the other social sciences that it began to be scientifically developed. Personality includes all the elements of psychological characteristics that together contribute to inform and determine the emotional, behavioral and cognitive structures which grow to become permanent over time and express who the individual is (Mount, Murray, Steve, \& Rounds, 2005). In another definition, personality is described as the most characteristic and original compilation of an individual's affective state, types of behaviors, abilities and other psychological properties (Eriksen, 1984). A personality which is expressed as the psycho-physical systems that determine the behavior and thought characteristics of an individual's dynamic structure is an internal psychological characteristic which describes and at the same time reflects how an individual responds to his/her environment (Allport, 1961). This definition describes the internal characteristics as "the characteristics which differentiate one individual from another, in terms of such factors as class, title, properties and personal traits" (Schiffman \& Kanuk, 2004).

Significant personality types arise as a result of one or more of the basic factors that cause personality formation to take certain directions. Individuals can be classified into personality types when certain criteria are taken into consideration. The literature contains many theories and models for determining personality characteristics. All of these them rely on Carl Jung's (1927) personality theory because the effects of the personality types in Carl Jung's model can be seen (Keefe \& Ferrell, 1990). Jung's personality types in all personality theories, included Link's introverted and extroverted personality types, Littauer and Littauer's personality types, the Myers-Briggs personality model, the Type A and B personality identified by Freidman and Rosenman in the late 1960s, Holland's personality types and Goldberg's five-factor personality theory. The five-factor personality model was 
used in this research because it leads to a better conceptual framework for determining the characteristics that music teachers should possess (Keefe \& Ferrell, 1990).

In music literature there exists an important body of studies on personality traits (Çevik-Kılıç, 2017; Girgin, 2017). Kemp (1982) stated that music teachers were more extroverted compared to other artists and Kvet and Watkins (1993), in their study, pointed out the importance of being optimistic, energetic, patient, experienced in classroom management, sensitive towards students and willing to use teaching materials in order to be a successful music teacher. Teachout (2001) identified the first and foremost personal characteristics of music teachers as being 'artistical' and the other characteristics as being 'social' and 'investigative'. Another study investigating the role of personality on behaviors about music reported that individuals who were open-minded tend to gravitate towards the arts (Rentfrow \& Gosling, 2003). Furthermore, Pekmen and Çevik (2010) stated in their study that prospective music teachers in Turkey had artistic, social and traditional type personality features. The study by Çevik-K1lıç (2017) investigating the relationship between job satisfaction of teachers and their personality level of satisfaction reported that music teachers had scores on Extroversion, Conscientiousness and Openness, moderate scores on Neuroticism and low scores on Agreeableness. At the end of the analysis, it was found that there was a positive, statistically significant relationship between Neuroticism and Openness personality scores and job satisfaction.

Burnout is a concept associated with personality. One of the main studies investigating the effects of personality traits on burnout was conducted by Maslach and Goldberg (1998). According to Maslach (2003), burnout is a psychological syndrome that occurs in the long term as a reaction to stress-increasing factors in the workplace. In another definition by Freudenberger, as cited in Girgin (2015), burnout was described as a state of being unsuccessful, worn out or exhausted as a result of the heavy use or overuse of power, energy and other individual sources. Alternatively, burnout was defined as emotional exhaustion and the increase in depersonalization as a result of extreme desires (Maslach \& Goldberg, 1998). A review of the literature showed that the definition of burnout put forward by Maslach and Jackson (1981) stands as the most accepted and popular and in particular, it proposes three categories of burnout: emotional exhaustion, depersonalization and low personal accomplishment. The first of these dimensions, "Emotional Exhaustion", refers to the increase in work-derived exhaustion, emotional deterioration, extreme fatigue, energy loss and weariness; the second dimension, "Depersonalization" refers to negative attitudes and reactions towards serviced clients; and the third dimension, "Low Personal Accomplishment", refers to the feeling of failure and insufficiency that persons experience in their work (Sweeney, Summers, \& Scott, 2002).

The symptoms of burnout generally have physical, psychological and behavioral features. More specifically, the personal characteristics responsible for increasing burnout according to various studies are high level of education (Maslach \& Jackson, 1981), age (Patrick \& Lavery, 2007), work-related uncertainties (Schaufeli \& Peeters, 2000), being single or being married without children (Cordes \& Dougherty, 1993) and gender (Espeland, 2006). In addition to these factors, there are certain job-induced causes that increase burnout, including insufficient or unfair rewarding and work overload (Zellars, Hochwater, Perrewé, Hoffman, \& Ford, 2000). When these symptoms of burnout are associated with personality characteristics, age, level of education, marital status and gender play important roles. Personality is an important factor in the lives of individuals. Personality traits can be affected by gender (Forrest, Lewis, \& Shevlin, 2000). Differences in personality and burnout levels among individuals by gender are supported by research (Maslach \& Jackson, 1981). There are significant differences between gender and personality in research on personality traits (Eysenck \& Haapasalo, 1989; Feingold, 1994). Male outcome scores were higher than those of females (Shevlin, Bailey, \& Adamson, 2001) and females had higher neuroticism scores than males (Şahin \& Univar, 2010). It has been found that women had higher experiential openness scores than males (Allik, Laidra, Realo, \& Pullmann, 2004) and that women have higher scores for responsibility than men (Kopliman, 2007). Men have been found to have higher easygoingness scores than women (Rushton, Morgan, \& Richard, 2007). However, some research results show no significant differences between gender and personality (O. Ekinci \&A. Ekinci, 2013).

The effect of gender on burnout should also be discussed. Gender studies have not always yielded consistent results in the literature. However, when evaluated in terms of gender, female and male teachers may have different levels of burnout. The gender roles that are imposed on women and men affect the behavior of women and men in business life (Aven, Parker, \& McEnvoy, 1993). Studies have found that gender is related to burnout, and there were significant differences between the burnout levels of males and females (Akçamete, Kaner, \& Sucuoğlu, 2001). While gender is the subject this study, some previous studies have found that males experience more burnout (Friedman, 1991), some have found that women do (Maslach \& Jackson, 1981; Forlin, 2001) and some have found no difference (Farber, 2000). One study emphasized that males burnout levels in the exhaustion 
and desensitization subscales may be related to their gender roles, which are higher than the burnout levels of female students (Yılmaz, Zeyneloğlu, Kocaöz, Kısa, Taşkın, \& Eroğlu, 2009).

Clearly, burnout can result from a wide variety of reasons and cannot be reduced to simply working in a stressful work environment or having too many responsibilities. In general, the causes of burnout are associated with the possibility of realization of expectations. Burnout emerges in situations where the gap between the expectations of a person and the reality is large. Therefore, burnout can be, depending on the circumstances, attributed to demographic features, expectations and personality traits. Various studies were conducted to better understand the relationship between personality traits and burnout (Mills \& Huebner, 1998). In these studies, by associating the personality structure with burnout, it was implied that individual personality structures were related to burnout. Zellars et al. (2000) stated that the five personality traits-openness, responsibility, extroversion, conscientiousness and emotional balance-serve as the precursory factors of burnout.

Studies showed that occupational groups that were in face-to-face and close communication with individuals (such as nurses and teachers) were particularly vulnerable for burnout and that teachers experienced the highest level of burnout (Droogenbroeck, Spruyt, \& Vanroelen, 2014). In Turkey, a number of studies on burnout were conducted specifically with teachers, who, by the nature of their work, are in close interaction with individuals (Evci \& Aylar, 2017). These studies in Turkey were mostly conducted with prospective music teachers rather than with in-service music teachers and they aimed to discern their personalities by applying various theories (e.g. Five-Factor Model and Holland's Theory). In Çevik's (2011) study based on the Five-Factor Model, Turkish prospective music teachers were described as social, creative and enthusiastic and they were found to be satisfied with their occupations when they became music teachers in the future. In addition, the same study reported that the individuals whose openness and extroversion levels were high were satisfied with their departments. In another study, which was conducted using Holland's theory, the prospective music teachers were found to have artistic and social personality traits (Çevik, Perkmen, Alkan, \& Shelley, 2013). Çevik-Kılıç (2017), in his study which aimed to reveal the relationship between the personality of music teachers in Turkey and their job satisfaction, the Five-Factor Personality Model constituted the theoretical framework of the study. Based on the findings from the study, the Extroversion, Conscientiousness and Openness scores of the music teachers, who were working in various regions of Turkey, were high, Neuroticism scores were moderate and Agreeableness scores were low.

Identification of the personality traits is of substantial importance in so far as it serves to determine the degree to which personality one of the factors affecting burnout-influences burnout. In this respect, to explain personality the 'Five-Factor Personality Model' incorporates the different views on personality (Bacanl1, İlhan, \& Aslan, 2009). The Five-Factor Personality Model, which involves, in part, an analysis of words that individuals use to describe themselves and others, emerged after years of study. The model is alternatively known as "Big Five" (Guenole \& Chernyshenko, 2005), or as its acronym OCEAN, in reference to the names of the five dimensions of personality it uses, namely, Openness, Conscientiousness, Extroversion, Agreeableness and Neuroticism, all of which are briefly described in Table 1.

Table 1. Five-factor personality model (Santrock, 2006, p. 127)

\begin{tabular}{ccccc}
\hline Openness & $\begin{array}{c}\text { Conscientiousn } \\
\text { ess }\end{array}$ & Extroversion & Agreeableness & Neuroticism \\
\hline $\begin{array}{c}\text { Imaginative or } \\
\text { unimaginative }\end{array}$ & $\begin{array}{c}\text { Organized or } \\
\text { disorganized }\end{array}$ & $\begin{array}{c}\text { Sociable or } \\
\text { unsociable }\end{array}$ & $\begin{array}{c}\text { Helpful or } \\
\text { indifferent to } \\
\text { others }\end{array}$ & Calm or nervous \\
\hline $\begin{array}{c}\text { Interested in arts or } \\
\text { disinterested in arts }\end{array}$ & $\begin{array}{c}\text { Careful or } \\
\text { careless }\end{array}$ & $\begin{array}{c}\text { Cheerful or } \\
\text { cheerless }\end{array}$ & $\begin{array}{c}\text { Cooperative or } \\
\text { competitive }\end{array}$ & $\begin{array}{c}\text { Patient or } \\
\text { impatient }\end{array}$ \\
\hline $\begin{array}{c}\text { Open to new } \\
\text { relationships, } \\
\text { Closed to new } \\
\text { relationships }\end{array}$ & $\begin{array}{c}\text { Disciplined or } \\
\text { impulsive }\end{array}$ & $\begin{array}{c}\text { Dominant or } \\
\text { unobtrusive }\end{array}$ & $\begin{array}{c}\text { Meek or } \\
\text { rebellious }\end{array}$ & $\begin{array}{c}\text { Anxious or } \\
\text { easygoing }\end{array}$ \\
\hline
\end{tabular}

Studies on the Five-Factor Personality Model focused largely on reviewing the scale's five-factors (Piedmont, McCrae, \& Costa, 1991) as they apply to music education issues (Chamorro-Premuzic \& Furnham, 2007; Çevik, 2011; Çevik et al., 2013; Çevik-K1lı̧, 2017). Only a very limited number of studies were conducted to investigate the relationship between personality and burnout issues (Innanen, Tolvanen, \& Salmela-Aro, 2014), 
while no study was found specifically examining the relationship between the burnout levels of music teachers and their personalities. By revealing the causes of burnout, the personality traits that are more vulnerable to burnout can be identified. This study is also important because it examined burnout and personality issues together. Specifically, this study aimed to determine the relationship between the burnout experienced by music teachers and their personality based on the Five-Factor Personality Model. The following research questions were formulated for this study:

- Do the personality types of music teachers change according to gender?

- Does burnout in music teachers change according to gender?

- What is the relationship between music teachers' personalities and their burnout?

- Are the personality types of music teachers a significant predictor of their burnout levels?

- According to the opinions of music teachers, what characteristics should music teachers have in the terms of personality types?

\section{Methodology}

\subsection{Research Method}

This is mixed method research, which incorporates qualitative and quantitative research techniques, methods and approaches (Johnson \& Onwuegbuzie, 2004). Quantitative methods provide access to many participants, while data obtained using qualitative methods such as observation and interviews allow for a more in-depth study of the research topic (Greene, Krayder, \& Mayer, 2005).

In the quantitative dimension of the study, causal comparison and relational screening were used for gender analysis. Correlational research is designed to determine the relationship between burnout and personality. Another dimension of this research is its qualitative dimension. This study is a case study with a qualitative research design. Case study is a systematic pattern type that includes the steps of gathering information, organizing gathered information, interpreting and obtaining research findings (Merriam, 1988, cited in Vural \& Cenkseven, 2005). In addition, case study is a qualitative research model that involves in-depth research of one or more situations in their natural environment (Yin, 2003). Analyses were done to determine the frequency of the qualitative data obtained by the research. The frequency (f) distributions of the responses given by the teachers to each question are shown in tables. The letter $\mathrm{f}$ in the tables indicates the frequency of repetition.

\subsection{Sample of the Study}

The data for the quantitative dimension of the study were collected from the participants who were selected through the convenience sampling method. The music teachers worked in four different geographical regions of Turkey. The convenience-case sampling method provides research with speed and practicality, as with this method the researcher selects cases which are nearby and easy to access (Yıldırım \& Şimşek, 2008). Among the 278 music teachers, 188 were female and 90 were male.

The qualitative dimension of the study involved semi-structured interviews conducted with 5 music teachers, who were selected through the purposive sampling method. The teachers who scored the highest in each personality type on the Adjective Based Personality Test were selected to participate in the qualitative portion of the research. These teachers were contacted and voluntarily agreed to participate in the interview.

\subsection{Data Collection Tools}

The survey applied in this study was composed of four sections. The first section was used to gather background information on the participants. The second section included the "Adjective Based Personality Test" (ABPT), which was developed by Bacanlı et al. (2009). The ABPT features a five-factor structure: Openness (8 items), Conscientiousness ( 7 items), Extroversion (9 items), Agreeableness (9 items) and Neuroticism ( 7 items). The scale is a 7-point Likert-type scale, where the items are arranged in a binary fashion, being composed of 40 antonym adjective couples. Scores from each dimension can range between 1 and 7 , with higher scores being an indication that the participant has the particular personality characteristic in question. Bacanlı et al. (2009), in their study titled, "Principle Components Factor Analysis", obtained data from 285 students. From this study, it was determined that the five-dimension scale explained $52.6 \%$ of the total variance. The validity and reliability of the test developed by Bacanlı et al. (2009) were confirmed and the internal consistency coefficient of the test ranged from .79 to .89 . The validity scores of ABPT, which were obtained by a re-test of each sub-dimension of the scale, were found as .73 for neuroticism, .89 for extroversion, .80 for openness, .87 for agreeableness and .80 for conscientiousness. The Cronbach's alpha coefficients obtained in this study were found to be .76 for extroversion, .71 for agreeableness, .72 for conscientiousness, .73 for neuroticism and .71 for openness. 
In the third section, which involved the assessment of burnout, the Maslach Burnout Inventory was used. The Maslach Burnout Inventory (MBI) was developed by Maslach and Jackson (1981). The scale is composed of 22 items and three dimensions, with 9 items of the scale belonging to "emotional exhaustion", 5 items belonging to "depersonalization" and 8 items belonging to "low personal accomplishment". The scale was adapted to Turkish by Ergin (1992), with some modifications being made. While originally the scale was 7-point Likert type, it was found that this type was not appropriate for Turkish culture. Therefore, the response options on the scale were reduced to a 5-point Likert. The structure of items was rearranged as follows: (0) Never, (1) Seldom, (2) Sometimes, (3) Most of the Time, (4) Always. The sub-scale scores for Emotional Exhaustion (EE) and Depersonalization (D) were determined as (0) Never, (1) Seldom, (2) Sometimes, (3) Most of the Time, (4) Always for each item; while for Lack of Personal Accomplishment (LPA) this arrangement was reversed (Never: 4, Always: 0). Since the questions on the "lack of personal accomplishment" dimension were positive, in order to refer to burnout, they were reverse-coded and analyzed. In other words, by reverse scoring these questions, the high scores obtained from these questions indicated that burnout was high.

The validity and reliability of the Maslach Burnout Inventory were calculated in two ways by Ergin (1992). In the first method, internal consistency was calculated for each sub-dimension. According to the data collected from the experiment group of 522 participants, the reliability coefficients for the original form of the scale were found to be: .83 for emotional exhaustion, .65 for depersonalization and .72 for lack of personal accomplishment. As for the second method, the reliability of the scale was determined through test/retest. A total of 99 participants from the experimental group were contacted again and the reliability coefficients were calculated as: .83 for depersonalization, .72 for depersonalization and .67 for lack of personal accomplishment. In this respect, the reliability of the scale was .88 for emotional exhaustion, .76 for depersonalization and .74 for lack of personal accomplishment.

In the fourth section, 5 music teachers were interviewed to further shed light on the influence of personality on burnout. The qualitative data of the study were collected through a semi-structured interview form composed of two open-ended questions developed by the researcher. The semi-structured interview technique allows for revisions to be made during the course of the interview in the event that information not previously considered emerges during the interview (Özgüven, 2004). The researcher reviewed the related literature while preparing the semi-structured interview form. Field experts were contacted to evaluate the interview form in terms of content validity. The experts were asked to evaluate the questions to be used in the interview in terms of how well they covered the subject of the interview and their clarity and comprehensibility. After the revisions were completed according to the opinions of experts, a pilot study was conducted and the interview form was finalized. The form consisted of 2 questions in total. Interviews were conducted on an individual basis to help the participants feel relaxed, whereby they could explain their ideas freely. The interviews took 15-20 minutes for each participant and were audio-recorded. The following questions were asked to the teachers:

- "To what extent are you happy as a music teacher?"

- "According to the opinions of the teachers, which personality type is more suitable for being music a teacher?"

\subsection{Data Analysis}

For the first research question of the study "Do the personality types of music teachers' change according to gender?" the data were analyzed through independent samples t-test for the comparison of two variables. For the second research question "Does burnout in music teachers change according to gender?" the data were analyzed through independent samples t-test for the comparison of two variables. For the third research question of the study "What is the relationship between music teachers' personalities and their burnout?", a correlation analysis was conducted. For the fourth research question of the study "Are the personality types of music teachers a significant predictor of their burnout levels?" a multiple regression analysis was conducted. For the fifth research question of the study, "According to the opinions of music teachers, what characteristics should music teachers have in terms of personality types?", interviews were conducted. In addition to this fifth question, the interview also included the question "To what extent are you happy as a music teacher?"

The data collected through the semi-structured interview form, which was composed of open-ended questions, were analyzed through descriptive analysis. The descriptive analysis method enables data to be presented in a manner that relates it to the research questions of the study (Yıldırım \& Şimşek, 2008). The data obtained from descriptive analysis were summarized and interpreted according to the predetermined themes. These themes are personality types. For this analysis, direct quotations were often included to provide a clearer understanding of the participants' views. These direct quotations, along with explanations of the results based on these quotations, 
are of key importance to analysis of the data (Wolcott, 1990). In compliance with the confidentiality principle, the names of the teachers were not included in the study, instead separate pseudonyms were used for the male teachers (i.e. E1, E2, etc.) and the female teachers (K1, K2, etc.).

During the data analysis process;

The transcription of the interviews: The validity of the question items was determined according to expert opinions. All interviews conducted with the teachers were done using an audio-recorder. The audio-recordings were transcribed by the researchers and transferred to a word document.

Preparation of the coding scheme: The transcriptions for each of the teachers were recorded on a separate word document. A coding scheme was formed in line with the interview questions asked to the teachers. The data were analyzed according to the coding scheme and descriptive analysis was conducted in the form of frequencies, based on the questions on the interview form. Afterward, the obtained findings were interpreted by the researchers with the help of direct questions. The distribution of the frequencies of answers that teachers gave for each question was presented in the form of tables.

The validity of the study: The answers that teachers gave were coded by the researcher and a reliability analysis was conducted. In the calculation of the reliability, the reliability formula specified by Miles and Huberman (1994) (reliability = number of agreements/ (total number of agreements+disagreements) was used. In this respect, the reliability of the study was found to be $82.4 \%$. Since the reliability was determined to be higher than $70 \%$ this study was considered as reliable.

\section{Findings}

Table 2. The mean scores and standard deviation values of personality types of music teachers based on gender

\begin{tabular}{ccccccccccccc}
\hline Gender & $\mathrm{N}$ & \multicolumn{2}{l}{ Extroversion } & \multicolumn{2}{l}{ Conscientiousness } & \multicolumn{2}{c}{ Openness } & Agreeableness & Neuroticism \\
\hline & & $\bar{X}$ & $\mathrm{SD}$ & $\bar{X}$ & $\mathrm{SD}$ & $\bar{X}$ & $\mathrm{SD}$ & $\bar{X}$ & $\mathrm{SD}$ & $\bar{X}$ & $\mathrm{SD}$ \\
\hline Female & 157 & 3.96 & .64 & 3.81 & .56 & 3.26 & .53 & 3.59 & .46 & 2.86 & .51 \\
\hline Male & 121 & 3.88 & .66 & 3.76 & .63 & 3.25 & .51 & 3.65 & .41 & 2.71 & .48 \\
\hline
\end{tabular}

Looking at Table 2, it can be clearly seen that in the extroversion dimension, the female participants $(\bar{X}=3.96$, $\mathrm{SS}=.64)$ had a higher mean score than the male participants $(\bar{X}=3.88, \mathrm{SS}=.66)$ that in the conscientiousness dimension, the female participants ( $\bar{X}=3.81, \mathrm{SS}=.56$ ) had a higher mean score than the male participants $(\bar{X}$ $=3.76, \mathrm{SS}=.63)$ that in the openness dimension, the female participants $(\bar{X}=3.26, \mathrm{SS}=.53)$ had a higher mean score than the male participants $(\bar{X}=3.25, \mathrm{SS}=.51)$ that in the agreeableness dimension, the male participants ( $\bar{X}=3.65, \mathrm{SS}=.41)$ had a higher mean score than the female participants $(\bar{X}=3.59, \mathrm{SS}=.46)$ and that, finally, in the neuroticism dimension the female participants $(\bar{X}=2.86, \mathrm{SS}=.51)$ had a higher mean score than the male participants $(\bar{X}=2.71, \mathrm{SS}=.48)$.

Table 3. The mean scores and standard deviation values of music teachers on burnout sub-dimensions based on gender

\begin{tabular}{cccccccc}
\hline Gender & $\mathrm{N}$ & Emotional Exhaustion & Depersonalization & $\begin{array}{l}\text { Lack of Personal } \\
\text { Accomplishment }\end{array}$ \\
\hline & & $\bar{X}$ & SD & $\bar{X}$ & SD & $\bar{X}$ & SD \\
Female & 157 & 2.86 & .93 & 2.46 & .86 & 2.38 & .64 \\
Male & 121 & 2.92 & .97 & 2.43 & .91 & 2.26 & .61 \\
\hline
\end{tabular}

It can be seen from the data in Table 3 that in the emotional exhaustion dimension, the male participants ( $\bar{X}$ $=2.92, \mathrm{SS}=.97)$ had a higher mean score than the female participants $(\bar{X}=2.86, \mathrm{SS}=.93)$; that in the depersonalization dimension, the female participants $(\bar{X}=2.46, \mathrm{SS}=.86)$ had a higher mean score than the male 
participants $(\bar{X}=2.43, \mathrm{SS}=.91)$; and that in the lack of personal accomplishment dimension the females $(\bar{X}$ $=2.38, \mathrm{SS}=.64)$ had a higher mean score than the male participants $(\bar{X}=2.26, \mathrm{SS}=.61)$.

Table 4. The independent samples t-test results regarding personality types of music teachers based on gender

\begin{tabular}{cccccccccccc}
\hline & \multicolumn{2}{c}{ Extroversion } & \multicolumn{2}{c}{ Conscientiousness } & \multicolumn{2}{c}{ Openness } & \multicolumn{2}{c}{ Agreeableness } & \multicolumn{2}{c}{ Neuroticism } \\
\hline & $\mathrm{t}$ value & $\mathrm{p}$ & $\mathrm{t}$ value & $\mathrm{p}$ & $\mathrm{t}$ value & $\mathrm{p}$ & $\mathrm{t}$ value & $\mathrm{p}$ & $\mathrm{t}$ value & $\mathrm{p}$ \\
Gender & .95 & .34 & -.52 & .63 & -.18 & .84 & .44 & .61 & -2.38 & $.00^{*}$ \\
\hline
\end{tabular}
$*_{\mathrm{p}}<.05$.

Table 4 shows that there was a statistically significant difference in terms of neuroticism personality type according to gender $[\mathrm{t}=-2.38, \mathrm{p}<.05]$. There was, however, no statistically significant difference in the extroversion [ $\mathrm{t}=.95, \mathrm{p}>.05]$, conscientiousness $[\mathrm{t}=-.52, \mathrm{p}>.05]$, openness $[\mathrm{t}=-.18, \mathrm{p}>.05]$ and agreeableness $[t=.44, p>.05]$ dimensions according to gender.

Table 5. The independent samples t-test results regarding burnout sub-dimensions of music teachers based on gender

\begin{tabular}{ccccccc}
\hline & Emotional Exhaustion & \multicolumn{2}{c}{ Depersonalization } & \multicolumn{2}{c}{$\begin{array}{c}\text { Lack of Personal } \\
\text { Accomplishment }\end{array}$} \\
\hline \multirow{2}{*}{ Gender } & $\mathrm{t}$ value & $\mathrm{p}$ & $\mathrm{t}$ value & $\mathrm{p}$ & $\mathrm{t}$ value & $\mathrm{p}$ \\
& .87 & .35 & -.73 & .42 & -2.18 & $.02 *$ \\
\hline
\end{tabular}

$* \mathrm{p}<.05$.

Table 5 shows that there was a statistically significant difference in the lack of personal accomplishment sub-dimension of burnout according to the gender of the music teachers [ $t=-2.18, p<.05]$. More specifically, the female participants had statistically significant greater lack of personal accomplishment feelings compared to the male participants. However, no significant difference was found regarding the emotional exhaustion $[\mathrm{t}=.87$, $\mathrm{p}>.05]$ and depersonalization $[t=-.73, \mathrm{p}>.05]$ sub-dimensions.

Table 6. The relationship between music teachers in terms of burnout scale and its sub-dimensions and personality types

\begin{tabular}{|c|c|c|c|c|c|c|c|c|}
\hline Variable & Extroversion & Neuroticism & Conscientiousness & Agreeableness & Openness & $\begin{array}{c}\text { Emotional } \\
\text { Exhaustion }\end{array}$ & Depersonalization & $\begin{array}{l}\text { Lack of Personal } \\
\text { Accomplishment }\end{array}$ \\
\hline \multicolumn{9}{|l|}{ 1-Extroversion } \\
\hline 2-Neuroticism & $-.478 * *$ & & & & & & & \\
\hline 3-Conscientiousness & $.413 * *$ & $-.488 * *$ & & & & & & \\
\hline 4-Agreeableness & $.458 * *$ & $-.522 * *$ & $.489 * *$ & & & & & \\
\hline 5-Openness & $.554 * *$ & $-.272 * *$ & $.359^{* *}$ & $.338^{* *}$ & & & & \\
\hline $\begin{array}{l}\text { 6-Emotional } \\
\text { Exhaustion }\end{array}$ & $-.234 * *$ & $.423^{* *}$ & $-.228^{* *}$ & $-.161^{* *}$ & -.078 & & & \\
\hline 7-Depersonalization & $-.294 * *$ & $.421 * *$ & $-.368^{* *}$ & $-.431^{* *}$ & $-.126^{*}$ & $.568^{* *}$ & & \\
\hline $\begin{array}{l}\text { 8-Lack of Personal } \\
\text { Accomplishment }\end{array}$ & $-.504 * *$ & $.338^{* *}$ & $-.423^{* *}$ & $-.357^{* *}$ & $-.394^{* *}$ & $.135^{* *}$ & $.226^{* *}$ & \\
\hline $\begin{array}{l}\text { 9-Burnout } \\
{ }^{*} \mathrm{p}<.05 ; * * \mathrm{p}<.01\end{array}$ & $-.454 * *$ & $.541^{* *}$ & $-.446^{* *}$ & $-.413^{* *}$ & $-.254 * *$ & $.813 * *$ & $.791^{* *}$ & $.584^{* *}$ \\
\hline
\end{tabular}

Pearson correlation analysis was conducted to reveal the relationship between personality types and burnout and its sub-dimensions. The analysis of the findings showed that negative and statistically significant relationships 
existed between extroversion and emotional exhaustion $(\mathrm{r}:-.234, \mathrm{p}<.01)$, extroversion and depersonalization (r: $-.294, \mathrm{p}<.01$ ) and extroversion and lack of personal accomplishment (r: -.504, $\mathrm{p}<.01)$. Additionally, statistically significant positive relationships between neuroticism and emotional exhaustion ( $\mathrm{r}: 423, \mathrm{p}<.01)$, neuroticism and depersonalization (r:.421, $\mathrm{p}<.01)$ and neuroticism and lack of personal accomplishment $(\mathrm{r}: .338, \mathrm{p}<.01)$ were found.

Statistically significant negative relationships were found between conscientiousness and emotional exhaustion $(\mathrm{r}:-.228, \mathrm{p}<0.01)$, conscientiousness and depersonalization $(\mathrm{r}:-.368, \mathrm{p}<.01)$ and conscientiousness and lack of personal accomplishment $(\mathrm{r}:-.423, \mathrm{p}<.01)$; additionally, statistically significant negative relationships were found between agreeableness and emotional exhaustion ( $\mathrm{r}:-.161, \mathrm{p}<.01)$, agreeableness and depersonalization ( $\mathrm{r}$ : $-.431, \mathrm{p}<.01)$ and agreeableness and lack of personal accomplishment $(\mathrm{r}:-.357, \mathrm{p}<.01)$.

Another finding from the study revealed that there was no statistically significant relationship between openness and emotional exhaustion $(\mathrm{r}:-.078, \mathrm{p}<.01)$. On the other hand, statistically significant positive relationships between openness and depersonalization $(\mathrm{r}:-.126, \mathrm{p}<.01)$ and between openness and lack of personal accomplishment were found $(\mathrm{r}:-.394, \mathrm{p}<.01)$. Furthermore, statistically significant negative relationships were found between extroversion and general burnout $(\mathrm{r}:-.454, \mathrm{p}<.01)$, conscientiousness and general burnout ( $\mathrm{r}$ : $-.446, \mathrm{p}<.01)$, agreeableness and general burnout $(\mathrm{r}:-.413, \mathrm{p}<.01)$ and openness and general burnout $(\mathrm{r}:-.254$, $\mathrm{p}<.01$ ). These results showed that as the level of extroversion increased in music teachers, their level of burnout decreased; as their level of extroversion decreased, their level of burnout increased; as their level of conscientiousness or agreeableness increased, their level of burnout decreased; and finally, as their level of conscientiousness or agreeableness decreased, their level of burnout increased. Additionally, a statistically significant positive relationship between neuroticism and general burnout was found ( $\mathrm{r}: .541, \mathrm{p}<0.1)$, where, as the music teachers' level of neuroticism increased, their level of burnout increased and vice versa, as their level of neuroticism decreased, their level of burnout decreased as well.

Table 7. Multiple regression analysis regarding music teachers' burnout and personality types

\begin{tabular}{|c|c|c|c|c|c|c|c|c|c|}
\hline Model & $B$ & SHB & $\beta$ & $\mathrm{t}$ & $p$ & $\mathrm{R}$ & $\mathrm{R}^{2}$ & $\begin{array}{c}\mathrm{R}^{2} \\
\text { Chang } \\
\mathrm{e}\end{array}$ & $\begin{array}{l}\text { Durbin- } \\
\text { Watson }\end{array}$ \\
\hline \multicolumn{10}{|l|}{ Model } \\
\hline (F: 47.958, p: .00) & & & & & & .611 & .373 & .362 & 2.197 \\
\hline Fixed & 3.274 & .334 & & 9.774 & .000 & & & & \\
\hline 1. Extroversion & -.182 & .046 & -.215 & -4.008 & .000 & & & & \\
\hline 2. Neuroticism & .294 & .043 & .316 & 6.348 & .000 & & & & \\
\hline 3. Conscientiousness & -.196 & .052 & -.182 & -3.785 & .000 & & & & \\
\hline 4. Agreeableness & -.073 & .055 & -.067 & -1.373 & .174 & & & & \\
\hline 5. Openness & .036 & .052 & .034 & .648 & .522 & & & & \\
\hline
\end{tabular}

Independent Variable: Extroversion, Neuroticism, Conscientiousness, Agreeableness, Openness.

Dependent Variable: Burnout.

According to the $\mathrm{R}^{2}$ value in Table 7 , the variability observed in the music teachers' burnout level was explained by approximately $37 \%$ of the personality types. The F value obtained (47.958) revealed that the model was valid, as a whole, at the .01 significance level. Moreover, the Durbin-Watson value revealed that there was no autocorrelation for the model $(1.5<2.197<2.5)$. In other words, not all of the relationships between dependent and independent variables can be found as significant.

At the end of the study, it was found that the burnout variable was significantly influenced by the extroversion, neuroticism and conscientiousness dimensions of the personality types. The effects of agreeableness and openness, however, were not found as significant.

As it can be seen from Table 7, a one-unit increase in the music teachers' extroversion and conscientiousness characteristics caused a .215 and .182 decrease, respectively, in the burnout level, in cases where other variables remained constant. In addition to this, a one-unit increase in the music teachers' neuroticism characteristics led to a .316-unit increase in their burnout levels. The findings also revealed that when the music teachers had extroversion and conscientiousness characteristics, this had a decreasing effect on their burnout, while in the 
cases when music teachers had neuroticism characteristics, their burnout levels were shown to decrease.

Interviews:

The teachers were asked "To what extent are you happy as a music teacher?". The responses teachers gave for this question are shown in Table 8 . Some of the opinions were expressed by more than one teacher.

Table 8 . The teachers' responses to the question of "to what extent are you happy as a music teacher?"

\begin{tabular}{l}
\hline Opinions \\
\hline We love working in this profession. We are extremely happy with the music teaching profession. \\
We are happy with being a music teacher, since our profession has employment security. \\
We get enough respect and love from our students. Therefore, since we are appreciated, we are happy with the music teaching \\
profession. \\
We are happy with being a music teacher because we feel that some of our personality characteristics are suitable for the teaching \\
profession. \\
The low number of class hours and the general feeling that we are not as appreciated as we think we should be are the negative factors \\
that prevent us from being happy with our profession. \\
The insufficient attachment of importance demonstrated by the school principal towards our courses and the behavior of the school \\
principal are negative factors that affect our happiness with our profession. \\
We are happy with being a music teacher because of our healthy communication with the teachers in the school and of our ability to \\
create effective learning and teaching environments.
\end{tabular}

Table 8 shows that five of the teachers cited the school principals' behaviors and the insufficient attachment of importance demonstrated by the school principal towards music courses as reasons that negatively affected their occupational satisfaction; four of the teachers indicated that they were happy with being a music teacher in so far as they had a healthy relationship with the teachers in the school and they created an effective learning and teaching environment; three of the teachers pointed to the limited number of class hours and being unable to get the expected appreciation as negative causes that affected their happiness with being a music teacher; three teachers expressed that they loved working as a music teacher and that they were happy with the music teaching profession; another three of the teachers indicated that since they got enough respect and love, they were happy with the music teaching profession; and lastly, two of the teachers reported that they were happy with their profession due to the job security.

The following of the some of the direct statements made by the music teachers:

"I think my personality characteristics directly affect my satisfaction with the job. For instance, since I am social, open to innovation, have high job discipline and enjoy my job, these enable me to love my job. Being a music teacher requires both patience and discipline." (K1).

"Since I love my job, the feeling of success I get from my profession contributes a great extent to my being happy with my job" (K3).

"Along with the job security in my profession, being loved and respected by my students and colleagues contributes a great extent to my satisfaction with my job. However, the fact that the school principal does not encourage our activities and the lack of respect shown to my profession are the causes that negatively affect my job satisfaction" (E2).

For the second question the teachers were asked "Which personality type is most suitable for being a music teacher?". The teachers' responses to this question are presented in Table 9. Some of the teachers expressed more than one opinion.

Table 9. The teachers' answers to the question "which personality type is most suitable for being a music teacher?"

\begin{tabular}{lll}
\hline Theme & Coding & $\mathrm{f}$ \\
\hline \multirow{4}{*}{ Openness } & Interest in fine arts & 2 \\
& Openness to innovation & 4 \\
& Researcher & 3 \\
& Interest in arts & 5 \\
\hline
\end{tabular}




\begin{tabular}{lll}
\hline \multirow{2}{*}{ Conscientiousness } & Responsible & 3 \\
& Organized & 4 \\
& Powerful communication skills & 3 \\
\multirow{3}{*}{ Extroversion } & Social & 5 \\
& Entrepreneurial & 2 \\
\multirow{2}{*}{ Agreeableness } & Talkative & 4 \\
\multirow{2}{*}{ Neuroticism } & Tolerant & 4 \\
& Patient personality & 5 \\
\hline
\end{tabular}

In looking at Table 9, it can be seen that regarding music teaching, five of the participants felt that being interested in arts and being social and patient were necessary; four stated that being talkative, organized, tolerant, calm and open to innovation was necessary; three indicated that having strong communication skills, being responsible, being a researcher and having strong persuasiveness were necessary; and finally, two stated that being interested in fine arts and having entrepreneurial skills were necessary.

The following of the some of the direct statements made by the music teachers:

"A teacher who behaves with patience and persistence is a good teacher. In addition to this, the teachers who are sensitive to the arts, organized, idealist, disciplined, social, persistent, energetic, responsible, imaginative, patient and have strong communication skills should be music teachers" (K2).

"Since personal characteristics differ from one person to the next, I think people who are more tolerant, patient and have an interest in arts should be music teachers" (K3).

"People who like helping other people and enjoy this and who have the ability to express their ideas, are interested in arts, have strong senses and are social and patient are suitable candidates for being a music teacher" (E2).

\section{Discussion, Conclusion, and Recommendations}

The concept of burnout refers to a state of depletion in the internal resources or energy of an individual caused by the waste of energy and power, or unmet desires due to failure, or by being worn out or feeling overloaded (Ergin, 1992). Compared to other professions, burnout tends to be experienced more often by teachers, as the teaching profession requires high levels of sacrifice and effective communication (Baltaş \& Baltaş, 1991).

Burnout is a collection of the negative reactions that teachers give against the inequality between the teachers' perceived skills and against the requirements of the profession (Farber, 2000). Each individual is affected by burnout in different ways and the burnout levels of individuals who are working in the same environment may vary. This situation can be explained by the personalities of the individuals. As is the case for music teaching, in order to be a better teacher, the teaching profession requires the characteristics specified in the "Conscientiousness" dimension, namely, organization, persistence, responsibility, carefulness, perseverance, planning skills and discipline (Ryans, 1960). An ideal music teacher is expected to be an individual who reflects number of characteristic traits, including the characteristics of "Extroversion", which involves being lively, cheerful, effective, enthusiastic and social (Spokane, Luchetta, \& Richwine, 2002), the characteristics of "Openness", such as interest in arts, imagination, innovativeness and openness to new relationships, the characteristics of "Agreeableness", which includes being helpful, meek and tolerant and forgiving (Çevik, 2011) and lastly, the characteristics of "Neuroticism, which means being calm and patient. It is clear that the personalities of music teachers are important for the process of music training. In general, a music teacher is expected to be an individual who is interested in arts, imaginative, possesses stronger communication skills, extroverted, calm, patient, tolerant, helpful and open to innovation (Rohwer \& Henry, 2004).

A study reported that the teachers who were stressful, impatient and anxious were often intolerant and experienced burnout in their profession (Montgomery \& Rupp, 2005). Hallam (2006), in her study, reported that the teachers who were nervous were under more stress. These findings suggest that when music teachers are stressful they can be intolerant and rebellious. In this respect, individuals with certain personality characteristics are more inclined to experience burnout, while others may be less so. Additionally, individuals who do not work in places suitable to their personality characteristics face the danger of burnout. This is because the success of an individual in the workplace is in some measure contingent on his/her personality. In this respect, the main purpose of this study was to reveal the relationship between music teachers' level of burnout and their personality according to the Five-Factor Personality Model theory. 
According to the findings of the study, the examination of the personality types of music teachers in terms of gender showed that compared to the male teachers, the female teachers had higher mean scores in the extroversion, conscientiousness and openness dimensions, while the male teachers had higher mean scores than the female teachers in the agreeableness dimension. Further, it was found that the only personality type that showed a significant difference according to the gender of the music teachers was in the neuroticism dimension; otherwise stated, the females in the study had significantly higher neuroticism characteristics compared to the males. Since the teaching profession requires more patience compared to other professions, it is particularly important that teachers be calm. A study reported that the personality characteristics of the teacher should not be aggressive but rather, calm in order to be successful in the teaching profession (Telman \& Ünsal, 2004). Another study found that the ideal teacher temperament must be balanced, patient and peaceful (Katz \& Raths, 1985).

When the burnout sub-dimensions of music teachers were considered according to gender, it was found that the males had a higher burnout mean score in the emotional exhaustion dimension; however, in terms of depersonalization and lack of personal accomplishment, the females had a higher mean score of depersonalization and lack of personal success. In studies investigating whether burnout sub-dimensions differ according to gender, the results varied, with some showing that there was no difference (Sepehrmanesh, Ahmadvand, Akasheh, \& Saei, 2010), some showing that females had higher levels of burnout (Riter, Kaiser, Hopkins, Pennington, Chamberlain, \& Eggett, 2007) and others that males had higher levels of burnout (Weckwerth \& Flynn, 2006). These findings confirm the results found in the present study.

In the present study, a statistically significant difference was observed regarding the lack of personal accomplishment, which is one of the sub-dimensions of burnout. According to this finding, females had a higher feeling of lack of personal accomplishment compared to that of males. These findings are consistent with those from previously conducted studies (Ergin, 1992). It is well known that music teachers engage in more school-related activities than teachers in other subjects. In addition to the class activities, music teachers undertake a role in many of the activities organized in schools, such as ceremonies, feasts and commemorations. In this respect, because of these added responsibilities, music teachers are expected to have a high sense of personal accomplishment. The fact that there was no statistically significant difference between the genders in terms of the emotional exhaustion and depersonalization dimensions can be explained by the similar job conditions and similar expectations that both male and female teachers face.

Another finding from the study was the negative significant relationship between extroversion and emotional exhaustion and depersonalization and lack of personal accomplishment as determined in the correlation analysis conducted. Other studies that performed support these findings (Bakker, Van Derzee, Lewig, \& Dollard, 2006; Zellar et al., 2000). In effect, these results suggest that the teachers who are more balanced, meek, open and responsible feel the effect of burnout less. In other studies, a statistically significant negative relationship was found between burnout and personality (Mills \& Huebner, 1998).

In the present study, statistically significant positive relationships were found between neuroticism and emotional exhaustion and depersonalization and lack of personal accomplishment. As it can be understood from this finding, individuals with neuroticism show intensive burnout symptoms. In other words, the people who are angry, impatient, pessimistic, nervous, restless and anxious experience burnout intensely. Therefore, it is quite important that music teachers have a calm and balanced temper. Judge, Heller, and Mount (2002) stated in their study that since the individuals who have a balanced temperament are more satisfied with their jobs they experience less burnout. Various studies conducted in this field support this finding (Bakker et al., 2006; Swider \& Zimmerman, 2010). The fact that the relationship between emotional imbalance and emotional exhaustion was positive suggests that the teachers with less control over their emotions may have higher emotional exhaustion levels. As a requirement of their profession, teachers spend more time with children and this makes them more emotional-oriented. This situation can be related to the increase in their emotional exhaustion levelata consistent rate. Individuals who got high scores in the neuroticism characteristic tended to get a high score in the depersonalization sub-dimension as well. Various studies found results similar to this finding (Bakker et al., 2006; Lingard, 2003). Moreover, the studies which showed there to be a significant positive relationship between neuroticism and lack of personal accomplishment also support this finding (Bakker et al., 2006; Zellar et al., 2000).

In yet another finding from the study, significant negative relationships were found between conscientiousness and emotional exhaustion and depersonalization and lack of personal accomplishment. The study conducted by Okutan (2010) reported results that were in agreement with this finding. In a different study, extroversion and conscientiousness were determined to be the personality types which have the highest level of relationship with burnout dimensions (Cano-Garcia, Padilla-Munoz, \& Carrasco-Ortiz, 2005). The present study also observed 
there to be significant negative relationships between agreeableness and emotional exhaustion and depersonalization and lack of personal accomplishment. Individuals with high levels of agreeableness have the characteristics of being calm, cooperative, meek and helpful and therefore, it is believed that they may be more emotionally resistant (Okutan, 2010). A study suggested that agreeable individuals may be more successful in their work places because they are cooperative and easygoing (Piedmont et al., 1991). In another study, individuals with low levels of agreeableness were found to more easily undergo depersonalization when they had an insecure attitude (Cano-Garcia et al., 2005). In the present study, there was no statistically significant relationship between openness and emotional exhaustion. In addition to this, there were significant negative relationships between openness and depersonalization and lack of personal accomplishment. For instance, when the level of openness increased the level of depersonalization decreased. The findings of this study are in parallel with the findings of the study conducted by Zellars et al. (2000).

The results of this study revealed statistically significant negative relationships between burnout in general and extroversion, conscientiousness, agreeableness and openness. This suggests that as the extroversion levels of the music teachers increase, their level of burnout will decrease and that as their level of extroversion decreases their level of burnout will increase. Furthermore, it can be argued on the basis of the findings that as a music teacher's level of conscientiousness and agreeableness increases, their level of burnout will decrease and that as their level of conscientiousness and agreeableness decreases, their level of burnout will increase. In the present study, a statistically significant positive relationship was found between neuroticism and burnout in general. In other words, this finding can be interpreted in a way that suggests, as the music teacher's level of neuroticism increases, their level of burnout will increase as well and that as their level of neuroticism decreases, their level of burnout will decrease, too. Various studies produced results to support this finding (Schaufeli \& Peeters, 2000; Zellars et al., 2000).

Results from the regression analysis conducted in this study showed that the burnout variable was significantly affected by the extroversion, neuroticism and conscientiousness dimensions of personality types, while the effects of agreeableness and openness were not significant. In line with this result, the extroversion and conscientiousness characteristics of music teachers had a decreasing effect on burnout, while neuroticism had an increasing effect.

According to the interviews conducted in the study, the music teachers were satisfied with their jobs for a number of different reasons, such as having personal characteristics suitable for the profession of music teaching, having respect and love for the students, having good communication with their colleagues and having the ability to create effective learning environments. This study revealed that the school environment and spending time with colleagues had an effective impact on the job satisfaction of the teachers. In contrast to this, the approach school principals took towards the music course, the limited number of music class hours and the lack of appreciation in their jobs had a negative effect on their professional satisfaction and increased their burnout (Cockburn \& Haydn, 2004). Further, music teachers stated that the school principals' lack of encouragement in their activities and lack of value towards their profession negatively affected their professional satisfaction. Factors such as salary, job security, working conditions, friendly environment and appreciation were found to have important effects on professional satisfaction and burnout (Can \& Soyer, 2008). This suggests that teachers who do not have professional satisfaction experience intense exhaustion. These findings support the results of the present study.

The interviews with music teachers revealed that the personality type dimensions with the highest scores were openness and extroversion, emotional imbalance, responsibility and easygoingness. The quantitative dimension of the research also emphasizes the importance of having extraordinary and responsible personality types. The results of the work, both quantitative and qualitative, support each other. Research in the literature emphasizes that the profession of music teaching is suitable for individuals who have artistic, social, open to change, organized, plan-oriented, ambitious, imaginative, responsible, talkative, calm and patient personality characteristics (Barrick \& Mount, 1991). These findings support the results of this research. A study by Dormann and Zapf (2001) reported that personality characteristics were important, in so far as the personality of an individual had an effect on his/her professional satisfaction and burnout. Other studies from the literature indicated that personality plays an important role in both the success of music teaching and the potential for teachers to experiencing professional burnout (Krueger, 1976). In this respect, it is believed that since job security, the feeling of success and the respect and love shown by their students and colleagues will provide music teachers with professional satisfaction, these factors will strongly contribute to their avoidance of professional burnout.

In conclusion, the teaching profession requires strength, patience, attention and effort. A teacher is expected to 
set a model for the students with his/her personality and to teach love and respect by establishing effective communication with his/her students. A music teacher will be more successful in meeting these expectations, given that they have effective communication skills in interpersonal relationships and are patient, imaginative, helpful, open to innovation, calm, self-confident and are able to motivate their students. Teachers who cannot meet these expectations will experience the feeling of burnout, which may even lead to them deciding to leave their jobs because they are unhappy with their professions. Needless to say, this situation would negatively affect the quality of education. In this respect, the personality characteristics of an individual are important in terms of experiencing burnout in a profession. The possibility of experiencing burnout differs between individuals, even if they work under the same conditions, the fact of which can be explained by the personalities of individuals, as individuals with certain personality characteristics are more inclined to experience burnout while others are not. Therefore, the success of individuals in the profession is related to their personality. Individuals who do not work in professions that are suitable to their personality characteristics are more vulnerable to the risk of burnout.

In the light of the findings of this study, the following recommendations can be made:

- Music departments which accept students through special talent exams may administer an interview and/or personality test to the applicants. In this way, the individuals who have the qualifications that are required for the music teaching profession can become music teachers.

- Teachers should be informed about burnout syndrome. Consultancy services can be provided in schools for this issue.

- Among the music teachers, for those who are vulnerable to burnout, programs to deal with burnout can be developed.

- Replicating this study and investigating other variables that may have relationships with burnout can provide important contributions to the literature.

- The examination of the studies that were conducted on burnout showed that most of them used quantitative methods. In this respect, the use of qualitative designs, which provide an in-depth analysis in studies, is recommended.

\section{References}

Akçamete, G., Kaner, S., \& Sucuoğlu, B. (2001). Öğretmenlerde tükenmişlik, iş doyumu ve kişilik. Ankara: Nobel Yayınevi.

Allik, J., Laidra, K., Realo, A., \& Pullmann, H. (2004). Personality development from 12 to 18 years of age: Changes in mean levels and structure of traits. European Journal of Personality, 18, 445-462. http://dx.doi.org/10.1002/per.524

Allport, G. W. (1961). Pattern and growth in personality. New York: Holt, Rinehart and Winston.

Aven, F. F., Parker, B., \& McEnvoy, G. M. (1993). Gender and attitudinal commitment to organizations: A meta analysis. Journal of Applied Psychology, 72, 642-648. http://dx.doi.org/10.1016/01482963(93)900430

Bacanlı, H., İlhan, T., \& Aslan, S. (2009). Beş faktör kuramına dayalı bir kişilik ölçeğinin geliştirilmesi: Sıfatlara dayalı kişilik testi (SDKT). Türk Ë̆itim Bilimleri Dergisi, 7(2), 261-279.

Bakker, A. B., Van der Zee, K. I., Lewig, K. A., \& Dollard, M. F. (2006). The relationship between the big five personality factors and burnout: A study among volunteer counselors. The Journal of Social Psychology, 146(1), 31-50. http://dx.doi.org/10.3200/SOCP.146.1.31-50

Baltaş, Z., \& Baltaş, A. (1991). Stres ve başa çıkma yolları. Ankara: MESS Yayını.

Barrick, M. R., \& Mount, M. K. (1991). The Big Five personality dimensions and job performance: A metaanalysis. Personnel Psychology, 44, 1-26. http://dx.doi.org/10.1111/j.1744-6570.1991.tb00688.x

Can, Y., \& Soyer, F. (2008). Beden eğitimi öğretmenlerinin sosyo-ekonomik beklentileri ile iş tatmini arasındaki ilişki. Gazi Üniversitesi Eğitim Fakültesi Dergisi, 28(1), 61-74.

Cano-Garcia, F. J., Padilla-Munoz, E. M., \& Carrasco-Ortiz, M. A. (2005). Personality and contextual variables in teacher burnout. Personality and Individual Differences, 38, 929-940. http://dx.doi.org/10.1016/j.paid.2004.06.018

Çevik, B. (2011). Personality self-perceptions of Turkish music pre-service teachers in relation to departmental satisfaction. International Journal of Music Education, 29, 212-228. http://dx.doi.org/10.1177/0255761410396282. 
Çevik, B., Perkmen, S., Alkan, M., \& Shelley, M. (2013). Who should study music education? A vocational personality approach. Music Education Research, 15(3), 341-356. http://dx.doi.org/10.1080/14613808.2013.788140

Çevik-Kılıç, D. B. (2017). Türkiye'deki müzik öğretmenlerinin kişilikleri ve iş tatminleri. Kastamonu Üniversitesi Kastamonu Eğitim Dergisi, 25(1), 435-454. https://doi.org/10.24106/kefdergi.309194

Chamorro-Premuzic, T., \& Furnham, A. (2007). Personality and music: Can traits explain how people use music in everyday life? British Journal of Psychology, 98, 175-185. http://dx.doi.org/10.1348/000712606X111177

Cockburn, A. D., \& Haydn, T. (2004). Recruiting and retaining teachers: Understanding why teachers teach. London, England: Routledge Falmer. https://doi.org/10.4324/9780203464854

Cordes, C. L., \& Dougherty, T. W. (1993). A review and in integration of research on job burnout. Academy of Management Review, 18(4), 621-656. http://dx.doi.org/10.5465/AMR.1993.9402210153

Dormann, C., \& Zapf, D. (2001). Job satisfaction: A meta-analysis of stabilities. Journal of Organizational Behavior, 22, 483-504. http://dx.doi.org/10.1002/job.98

Droogenbroeck, F. V., Spruyt, B., \& Vanroelen, C. (2014). Burnout among senior teachers: Investigating the role of workload and interpersonal relationships at work. Teaching and Teacher Education, 43, 99-109. http://dx.doi.org/10.1016/j.tate.2014.07.005

Ekinci, O., \& Ekinci, A. (2013). Major duygudurum bozukluklarında kişiliğin üç boyutlu değerlendirilmesi ve klinik özelliklerle ilişkisi. Nöropsikiyatri Arşivi, 50, 15-22. https://doi.org/10.4274/npa.y6181

Ergin, C. (1992). Doktor ve hemşirelerde tükenmişlik ve Maslach tükenmişlik ölçeğinin uyarlanması. VII. Ulusal psikoloji kongresi bilimsel çalışmaları içinde (s. 143-154), Ankara: VII. Ulusal Psikoloji Kongresi Düzenleme Kurulu ve Türk Psikologlar Derneği. September 22-25.

Eriksen, E. H. (1984). İnsanın sekiz çağı (B. Üstün, V. Şar, Çev.). Ankara: Birey ve Toplum Yayıncılık.

Espeland, K. E. (2006). Overcoming burnout: How to revitalize your career. The Journal of Continuing Education in Nursing, 37(4), 178-184. http://dx.doi.org/10.3928/00220124-20060701-04

Evci, N., \& Aylar, F. (2017). Öğretmenlerde tükenmişlik düzeyleri öz-alg1 ölçeğinin geliştirilmesi: Geçerlik ve güvenirlik çalışması. Gazi Eğitim Bilimleri Dergisi (GEBD), 3(1), 44-58.

Eysenck, S. G. B., \& Haapasalo, J. (1989). Cross-cultural comparisons of personality: Finland and England. Personality and Individual Difference, 10(1), 121-125. http://doi.org/10.1016/0191-8869(89)90188

Farber, B. (2000). Introduction: Understanding and treating burnout in a changing culture. Psychotheraphy in Practice, $\quad 56(5)$ 589-594. http://dx.doi.org/10.1002/(SICI)10974679(200005)56:5<589::AIDJCLP1>3.0.CO;2-S

Feingold, A. (1994). Gender differences in personality: A meta-analysis. Psychological Bulletin, 116, 429-456. http://dx.doi.org/10.1037/0033- 2909.116.3.429

Forlin, C. (2001). Inclusion: Identifying potential stressors for regular class teachers. Educational Research, 43(3), 235-245. http://dx.doi.org/10.1080/00131880110081017

Forrest, S., Lewis, C. A., Shevlin, M. (2000). Examining the factor structure and gender bias of the Eysenck personality questionnaire revised-abbreviated. Personality and Individual Difference, 29(3), 579-588. http://dx.doi.org/10.1016/S0191-8869(01)00049-6

Friedman, I. A. (1991). High-and low-burnout schools: School culture aspects of teacher burnout. Journal of Educational Research, 84(6), 325-333. http://dx.doi.org/10.1080/00220671.1991.9941813

Girgin, D. (2015). Bireysel çalgı dersi tükenmişlik ölçeği geliştirme çalışması: Geçerlik ve güvenirlik analizi. Bartın Üniversitesi Eğitim Fakültesi Dergisi, 4(1), 115-126. https://doi.org/10.14686/BUEFAD.2015111019

Girgin, D. (2017). The relationship between pre-service music teachers' self-efficacy belief in musical instrument performance and personality traits. Eurasian Journal of Educational Research (EJER), 67, 107-123. http://dx.doi.org/10.14689/ejer.2017.67.7

Greene, J. C., Krayder, H., \& Mayer, E. (2005). Combining qualitative and quantitative methods in social inquiry. In B. Somekh, \& C. Lewin (Eds.). Research methods in the social sciences (pp. 275-282). London: Sage. 
Guenole, N., \& Chernyshenko, O. S. (2005). The suitability of Goldberg's Big Five IPIP personality markers in New Zealand: A dimensionality, bias and criterion validity evaluation. New Zealand Journal of Psychology, 34, 86-96.

Hallam, S. (2006). Music psychology in education. London: Institute of Education, University of London.

Innanen, H., Tolvanen, A., \& Salmela-Aro, K. (2014). Burnout, work engagement and work a holism among highly educated employees: Profiles, antecedents and outcomes. Burnout Research, 1, 38-49. http://dx.doi.org/10.1016/j.burn.2014.04.001

Johnson, R. B., \& Onwuegbuzie, A. J. (2004). Mixed methods research: A research paradigm whose time has come. Educational Researcher, 33(7), 14-26. https://doi.org/10.3102/0013189X033007014

Judge, T. A., Heller, D., \& Mount, M. K. (2002). Five-factor model of personality and job satisfaction a Meta analysis. Journal of Applied Psychology, 87(3), 530-541. http://dx.doi.org/10.1037//00219010.87.3.530

Katz, L. G., \& Raths, J. D. (1985). Dispositions as goals for teacher education. Teaching and Teacher Education, 1(4), 301-307. http://dx.doi.org/10.1016/0742-051X(85)90018-6

Keefe, W., \& Ferrell, B. (1990). Developing a defensible learning style paradigm. Educational Leadership, 48(2), 57-61.

Kemp, A. E. (1982). Personality traits of successful music teachers. Psychology of Music, 72-75.

Kopliman, S. (2007). Ögretmenlerin kişilik özelliklerinin öğrencilere not verme davranışları üzerindeki etkisi (Yüksek Lisans Tezi). Beykent Üniversitesi, İstanbul.

Krueger, R. J. (1976). An investigation of personality and music teaching success. Bulletin of the Council for Research in Music Education, 47, 16-25.

Kvet, E. J., \& Watkins, R. C. (1993). Success attributes in teaching music as perceived by elementary education majors. Journal of Research in Music Education, 41, 70-80. https://doi.org/10.2307/3345481

Lingard, H. (2003). The impact of individual and job characteristics on burnout among civil engineers in Australia and the implications for employee turnover. Construction Management and Economics, 21, 69-80. http://dx.doi.org/10.1080/0144619032000065126

Maslach, C., \& Goldberg J. (1998). Prevention of burnout: New perspectives. Applied and Preventive Psychology, 7(1), 63-74. http://dx.doi.org/10.1016/S0962-1849(98)80022-X

Maslach, C. (2003). Job burnout: New directions in research and intervention. Current Directions in Psychological Science, 12(5), 189-192. http://dx.doi.org/10.1111/1467-8721.01258

Maslach, C., \& Jackson, S. E. (1981). The measurement of experienced burnout. Journal of Occupational Behavior, 2, 99-113. http://dx.doi.org/10.1002/job.4030020205

Miles, M. B., \& Huberman, A. M. (1994). Qualitative data analysis. Thousand Oaks, CA: Sage.

Mills, L. B., \& Huebner, E. S. (1998). A prospective study of personality characteristics, occuparional stressors and burnout among school psychology practitioners. Journal of School Psychology, 36(1), 103-120. http://dx.doi.org/10.1016/S0022-4405(97)00053-8

Montgomery, C., \& Rupp, A. R. (2005). A meta-analysis for exploring the diverse causes and effects of stress in teachers. Canadian Journal of Education, 28(3), 458-486. http://dx.doi.org/10.2307/4126479

Mount, M. K., Murray, R. B., Steve, M. S., \& Rounds, J. (2005). Higher-order dimensions of the big five personality traits and the big six vocational interest types. Personnel Psychology, 58, 447-478. http://dx.doi.org/10.1111/j.1744-6570.2005.00468.x

Okutan, E. (2010). Kişilik özelliklerinin tükenmişliğe etkisi: Bir örnek olay incelemesi (Yayınlanmamış doktora tezi). Sakarya Üniversitesi Sosyal Bilimler Enstitüsü, Sakarya.

Özgüven, İ. E. (2004). Görüşme ilke ve teknikleri. Ankara: Pdrem Yayınları.

Patrick, K., \& Lavery, J. F. (2007). Burnout in nursing. Australian Journal of Advanced Nursing, 24(3), 125-132.

Perkmen, S., \& Çevik, B. (2010). Relationship between pre-service music teachers' personality and motivation for computer-assisted instruction. Music Education Research, 12(4), 415-425. http://dx.doi.org/10.1080/14613808.2010.519768

Piedmont, R. L., McCrae, R. R., \& Costa, P. T. (1991). Adjective check list scales and the five-factor model. Journal of Personality and Social Psychology, 60(4), 630-637. http://dx.doi.org/10.1037/00223514.60.4.630 
Rentfrow, P. J., \& Gosling, S. D. (2003). The do re mi's of everyday life: The structure and personality correlates of music preferences. Journal of Personality and Social Psychology, 84(6), 1236-1256. http://dx.doi.org/10.1037/0022-3514.84.6.1236

Riter, T. S., Kaiser, D. A., Hopkins, J. T., Pennington, T. R., Chamberlain, R., \& Eggett, D. (2007). Presence of burnout in undergraduate athletic training students. Athletic Training Education Journal, 2, 57-76.

Rohwer, D., \& Henry, W. (2004). University teachers' perceptions of requisite skills and characteristics of effective music teachers. Journal of Music Teacher Education, 13(2), 18-27. http://dx.doi.org/10.1177/10570837040130020104

Rushton, S., Morgan, J., \& Richard, M. (2007). Teacher's Myers-Briggs personality profiles: Identifying effective teacher personality. Teacher and Teacher Education, 23(1), 432-441. http://dx.doi.org/10.1016/j.tate.2006.12.011

Ryans, D. (1960). Characteristics of teachers. Washington, D.C.: American Council on Education.

Şahin, H., \& Ünüvar, P. (2010) Eğitim fakültesi öğrencilerinin empatik becerileri ve kişilik özelliklerinin incelenmesi. NWSA, Education Sciences, 6(1), 1216-1226.

Santrock, J. W. (2006). Educational psychology. Boston, MA: McGraw Hill.

Schaufeli, W., \& Peeters, M. C. W. (2000). Job stress and burnout among correctional officers: A literature $\begin{array}{lllll}\text { review. International Journal of Stress Management, } & 7(1), & 19-48 .\end{array}$ http://dx.doi.org/10.1023/A:1009514731657

Schiffman, L. G., \& Kanuk, L. L. (2004). Consumer behavior, international edition. United States of America: Pearson Prentice Hall, pp. 120.

Sepehrmanesh, Z., Ahmadvand, A., Akasheh, G., \& Saei, R. (2010). Prevalence of burnout in senior medical students. European Psychiatry, 25(1), 723. http://dx.doi.org/10.1016/S0924-9338(10)70717-3

Shevlin, M., Bailey, F., \& Adamson, G. (2002). Examining the factor structure and sources of differential functioning of the Eysenck personality questionnaire revised abbreviated. Personality and Individual Difference, 32, 479-487. https://doi.org/10.1016/S0191-8869(01)00049-6

Spokane, A. R., Luchetta, E. J., \& Richwine, M. H. (2002). Holland's theory of personalities in work environments. In D. Brown (Ed.), Career choice and development (pp. 373-426). San Francisco, CA: Jossey Bass.

Sweeney, J. T., \& Summers, S. L. (2002). The effect of the busy season workload on public accountants' job burnout. Behavioral Research in Accounting, 14, 223-245. http://dx.doi.org/10.2308/bria.2002.14.1.223

Swider, B. W., \& Zimmerman, R. D. (2010). Born to burnout: A meta-analytic path model of personality, job burnout and work outcomes. Journal of Vocational Behavior, 76(3), 487-506. http://dx.doi.org/10.1016/j.jvb.2010.01.003

Teachout, D. J. (2001).The relationship between personality and teaching effectiveness of music student teachers. Psychology of Music, 29, 179-192. http://dx.doi.org/10.1177/0305735601292007

Telman, N., \& Ünsal, P. (2004). Çalışan memnuniyeti. İstanbul: Epsilon Yayıncılık.

Vural, R., \& Cenkseven, F. (2005). Eğitim araştırmalarında örnek olay (vaka) çalışmaları: Tanımı, türleri, aşamaları ve raporlaştırılması. Burdur Eğitim Fakültesi Dergisi, 6(10), 25-38.

Weckwerth, A. C., \& Flynn, D. M. (2006). Effect of sex on perceived support and burnout in university students. College Student Journal, 40(2), 237-249.

Wolcott, H. F. (1990). Writing up qualitative research (Sage qualitative research methods series, Vol. 20). Newbury Park, CA: Sage.

Yıldırım, A., \& Şimşek, H. (2008). Sosyal bilimlerde nitel araştırma yöntemleri. Ankara: Seçkin Yayınları.

Yılmaz, D. V., Zeyneloğlu, S., Kocaöz, S., Kısa, S., Taşkın, L., \& Eroğlu, K. (2009). Üniversite öğrencilerinin toplumsal cinsiyet rollerine ilişkin görüşleri. Uluslararası İnsan Bilimleri Dergisi, 6(1), 775-792.

Yin, R. K. (2003). Case study research design and methods. London: Sage Publications.

Zellars, K. L., Hochwater, W. A., Perrewé, P. L., Hoffman, N., \& Ford, E. W. (2000). Experiencing job burnout: The roles of positive and negative traits and states. Journal of Applied Social Psychology, 34(5), 887-911. http://dx.doi.org/10.1111/j.1559-1816.2004.tb02576.x 


\section{Copyrights}

Copyright for this article is retained by the author(s), with first publication rights granted to the journal.

This is an open-access article distributed under the terms and conditions of the Creative Commons Attribution license (http://creativecommons.org/licenses/by/4.0/). 